\title{
Cowden syndrome
}

\section{Abderrahmen Masmoudi, Zied Mohamed Chermi, Slaheddine Marrekchi, Ben Salah Raida, Sonia Boudaya, Madiha Mseddi, Meziou Taha Jalel, Hamida Turki}

Department of Dermatology, Hedi Chaker University Hospital, 3029 Sfax, Tunisia.

\section{Corresponding author: \\ Abderrahmen Masmoudi \\ Department of Dermatology, \\ Hedi Chaker Hospital \\ 3029 Sfax, Tunisia}

E-mail: masmoudiabd@yahoo.fr

\section{Key words:}

acitretin, Cowden syndrome, genodermatosis, gingiva, hamartoma, oral mucous membrane, papilloma, PTEN, etretinate

\section{Abstract}

Background: Cowden syndrome is a rare genodermatosis charactarized by presence of multiple hamartomas. The aim of the study was to specify the clinical, therapeutic and prognostic aspects of Cowden syndrome.

Cases report: Our study included 4 patients with Cowden syndrome, 2 males and 2 females between 14 and 46 years old. Clinical examination of the skin revealed facials papules (4 cases), acral keratosis (1 case), translucent keratotic papules ( 2 cases). Oral examination revealed papules (4 cases), papillomatosis (4 cases), gingival hypertrophy (4 cases) and scrotal tongue (2 cases). Investigations revealed thyroid lesions (2 cases), fibrocystic disease and lipoma of the breast in 1 case, "glycogenic acanthosis" (1 case), macrocephaly (2 cases), dysmorphic face ( 1 case) and lichen nitidus (1 case). Oral etretinate and acitretine were temporary efficient in 2 patients. Topical treatment with tretinoin lotion resulted in some improvement in cutaneous, but not mucosal lesions in one patient. No cancer was revealed.

Conclusion: The pathognomonic mucocutaneous lesions were found in all patients. However, no degenerative lesions have been revealed. A new association of Cowden syndrome with lichen nitidus was found. Treatment with oral retinoids was efficient on cutaneous lesions.

\section{Introduction}

Cowden syndrome (CS), also known as Cowden's disease or multiple hamartoma syndrome, is a rare genodermatosis with autosomal dominant pattern of transmission, ${ }^{1,2}$ described firstly by Lloyd and Dennis. ${ }^{2,3}$ Multiple mucocutaneous lesions are associated with involvement of other organs and systems including essentially goitre, thyroid cancer, fibrocystic breast disease and breast carcinoma, endometrial carcinoma and gastrointestinal polyps. ${ }^{4,5,6}$

\section{Case Reports}

\section{CASE 1}

A 46-year-old woman, was referred for papules of the buccal mucosa and verrucous lesions of the extremities that occurred three years before. She has a primary sterility and irregular menstrual cycles. Her parents were 1 st degree cousins and healthy. Her face was dysmorphic with macrocephaly (occipito-frontal head circumference $(\mathrm{OFC})=62 \mathrm{~cm}$ ).

On physical examination, we found 0,5 to $2 \mathrm{~mm}$ erythematous papules, partly translucent, located on the face (forehead, back of the nose, chin) and hands. Acral keratose lesions of 2 to $3 \mathrm{~mm}$ in diameter were sitting on the back of the feet (Fig. 1A), resembling to common warts. These lesions became confluent in limited zones of 1 to $2 \mathrm{~cm}$ in diameter, located on the back of the first left toe and the second right toe. Verrucous papules, which looked like common warts, of 2 to $3 \mathrm{~mm}$ in diameter, were situated on the right leg and the left forearm. We found also many translucent keratotic papules the hands palms (Fig. 1B), angiomas measuring 1 to $3 \mathrm{~mm}$ in diameter on the chest and on the back, small nævi on the back and some papules of 1 to $4 \mathrm{~mm}$ in diameter, grouped somewhere on lips and took a papillomatous aspect. Besides, there were cheilitis of the lower lip, some papules on the jugal mucosa measuring 1 to $2 \mathrm{~mm}$ in diameter, a scrotal tongue and a gingival hypertrophy sprinkled of papules and papillomas. The external genitalia examination, the hair and nails were normal. 
The examination of the cavum by cold light demonstrated a papule of a very small size on the lateral face of the cavum and another one in the hypopharynx. The abdomino-pelvic examination showed a farm painless pelvic mass making $17 \times 10 \mathrm{~cm}$ in size. Clinical uro-genital examination revealed at the vaginal touch an uterine fibroma.

Breast and thyroid ultrasonographies were normal. Thyroid scintigraphy was also normal. The abdominopelvic ultrasonography discovered bladder calculi and an uterine fibroma of 16x10 cm in size. Eso-gastro-duodenal endoscopy revealed multiple gastric polypoid lesions and a bulbar ulceration. The double contrast barium enema showed many polypoid lesions in the sigmoid and the descending colon. The eso-gastro-duodenal transit showed several incomplete and irregular pictures in the antral region evoking polypoid formations.

The biopsies of the lower lip and tongue lesions concluded to papillomas. The biopsies of a gastric polyp concluded to a polyadenoma.

The patient was treated with etretinate at the dose of $1 \mathrm{mg} / \mathrm{kg} /$ day during 2 months. She refused to undergo a surgical excision of the uterine fibroma. The patient was followed-up for 2 months. The cutaneous lesions regressed slightly. The mucous lesions, not modified by etretinate, were destroyed by electrocoagulation. After 2 years, a recurrence of cutaneous lesions was marked following the discontinuation of treatment.

\section{CASE 2}

A 21-year-old female, complained of papules on her hands and on the lips and gingival hypertrophy. She had a mastodiny and irregular menstrual cycles. Her parents were 1st degree cousins and healthy. Her youngest child presented gingival hypertrophy and her maternal grandmother had papules on the lips and gingival hypertrophy.

On physical examination, we found flat papules on the forehead and the nose measuring 2 to $3 \mathrm{~mm}$ in diameter, micro-papules on the hands palms of and two nevi on the neck. Oral examination showed cheilitis with multiple papules and verrucous lesions on the mucosa and the vermilion zone of the lower lip and a gingival hypertrophy scattered with papules measuring $2 \mathrm{~mm}$ in diameter. The external genitalia examination, the hair and nails were normal. She had moderate hepatomegaly.

FT4 was below the normal range at 0,05 pmol/l and TSH was $17,5 \mu \mathrm{Ul} / \mathrm{ml}$. Thyroid scintigraphy showed a unique right lobe with a cold histhmic nodule and the left lobe was invisible. Audiometry showed up a perception deafness of the left ear of $-20 \mathrm{~dB}$ for low frequencies. The breasts ultrasonography showed features of fibrocystic disease. The abdominopelvic ultrasonography and the abdominal TDM revealed a voluminous multi-partitioned liquid hepatic mass evoking firstly a hydatic cyst stage III. ELISA confirmed a hydatidosis at 1/2560. Digestive endoscopy showed multiple
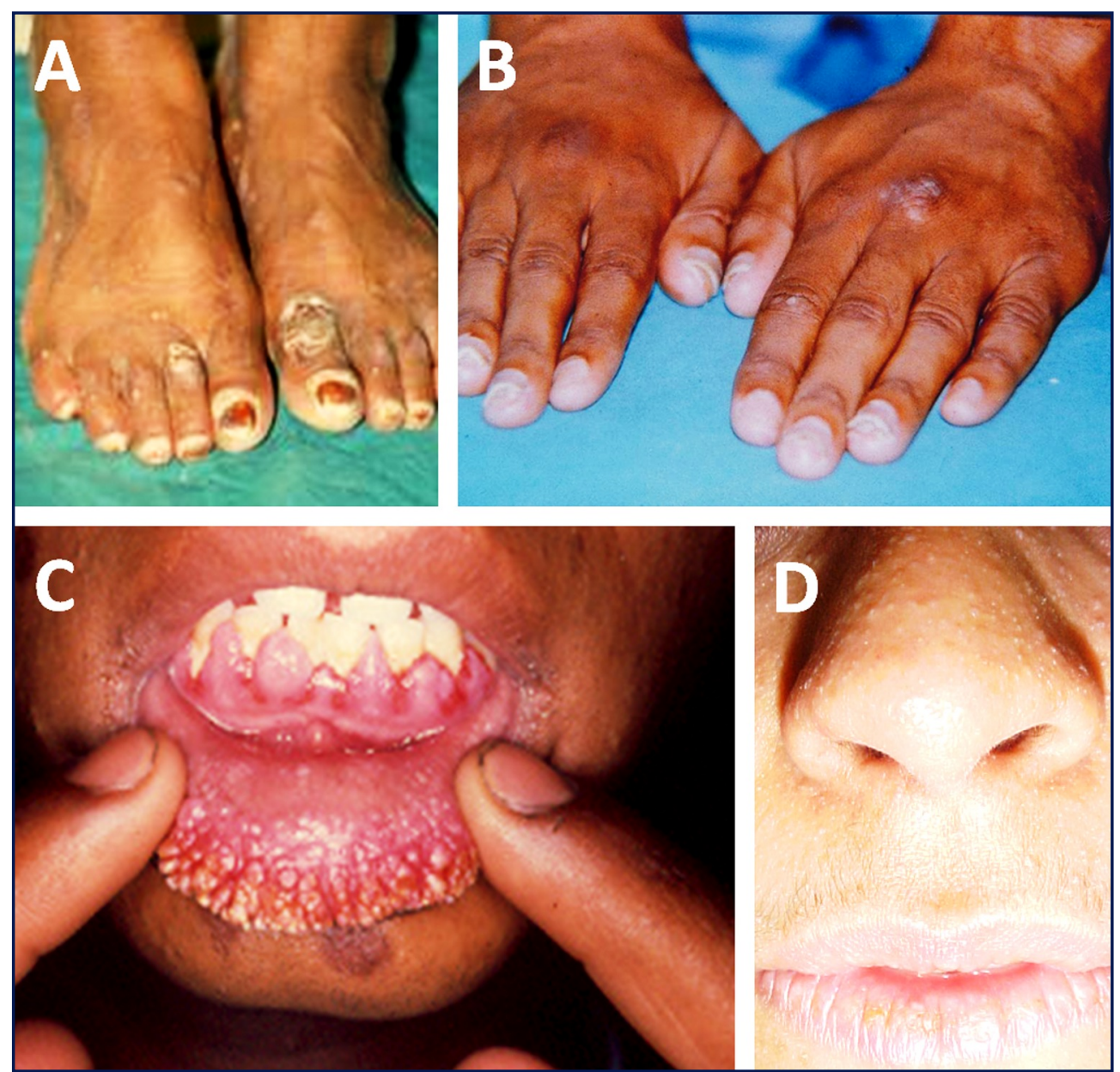

\section{Figure 1}

(A) Acral keratotic lesions of the feet (case1),

(B) Acral keratotic lesions of the dorsal aspect of hands (case 1), (C) Papillomas on hypertrophic gingival mucosa (case 3),

(D) Pinkish papules of the nose (case 4). 
papules of the upper half of the oesophagus that can be a localization of CS. However, the biopsy of an oesophagic papule revealed a chronic oesophagitis evocating a "glycogenic acanthosis".

Treatment with acitretine was not applied because of the young age and the hepatic disease. Surgical interventions for the thyroid nodule and for the hydatic cyst of the liver were refused by the patient. The follow-up of the patient for 2 months was marked by the stability of the stability of all lesions.

\section{CASE 3}

A 14-year-old male patient, the youngest brother of the previous patient (Case 2), presented with gingival hypertrophy from the age of 8 (Fig. 2).

Physical examination showed papillomas measuring up to $5 \mathrm{~mm}$ in diameter on a hypertrophic upper gingival mucosa (Fig. 1C). The external genitalia examination, the scalp and nails were normal.

Thyroid function test and scintigraphy, digestive endoscopy, barium enema and abdominopelvic ultrasonography were normal.

The treatment by acitretine was not proposed because of the young age. The follow-up of the patient for one month was marked by the stability of all lesions.

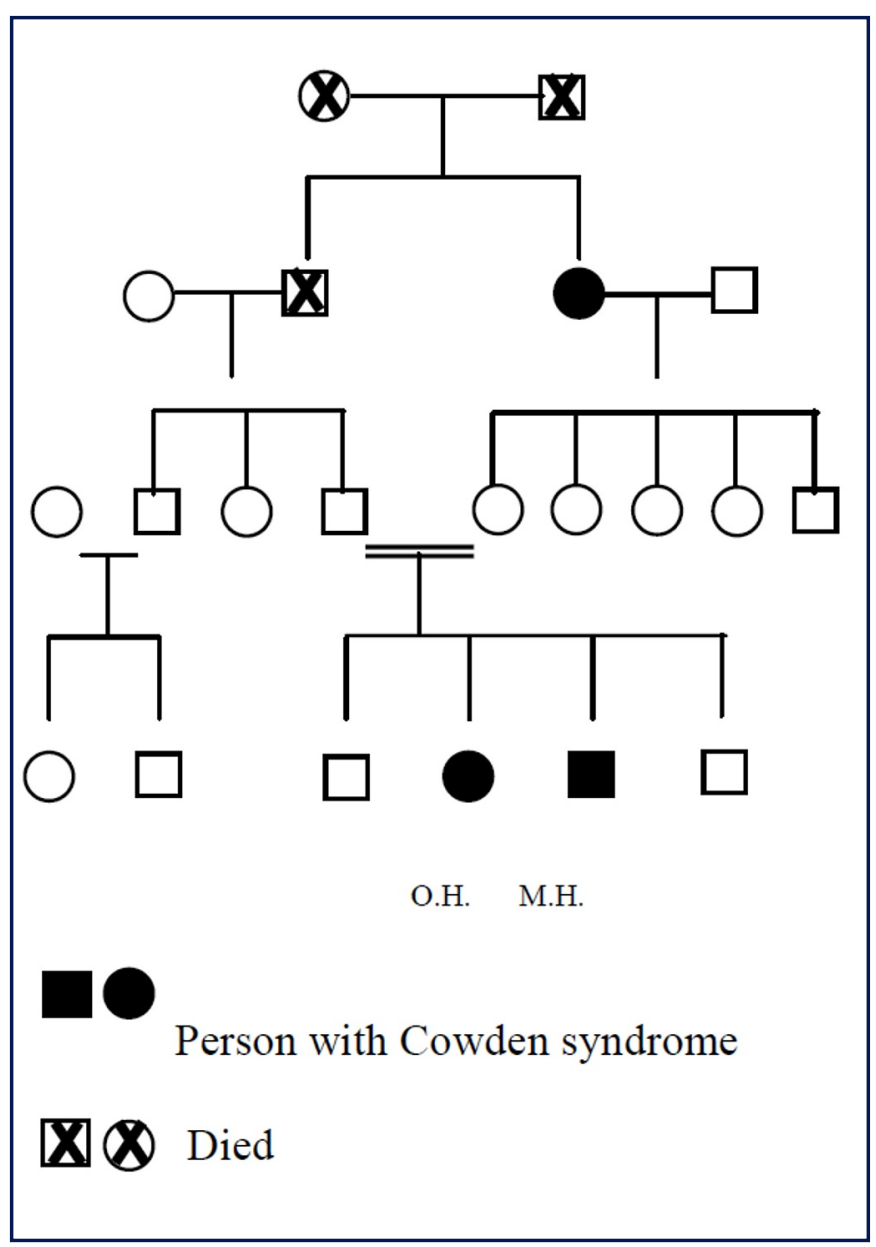

Figure 2

Cases 2 and 3. Family pedigree.

\section{CASE 4}

A 26-year-old female, consulted for investigation of papulo-verrucous lesions on the face and the limbs associated to a macrocephaly $(\mathrm{OFC}=60 \mathrm{~cm})$.

Cutaneous examination showed flesh coloured or pinkish papules of 1 to $2 \mathrm{~mm}$ in diameter located on the nose (Fig. 1D), the nasolabial area and around nostrils. Some pedonculated papules measuring 1 to $2 \mathrm{~mm}$ in diameter on the neck were present. Oral examination showed white papules on the lips measuring 1 to $2 \mathrm{~mm}$ in diameter and a gingival hypertrophy scattered by white-pearly papules measuring 1 to $2 \mathrm{~mm}$ in diameter regrouped in some places in cluster giving out a papillomatous aspect. The external genitalia examination, the hair and nails were normal.

Breast examination showed a soft mass, well limited, painless, of $5 \mathrm{~cm}$ in size and mobile in relation to the deep plan at the level of the upper-outer quadrant of the left breast evoking a lipoma. The thyroid function test was normal. Thyroid ultrasonography showed two hypoechogene well delineated nodules of the right lobe: an histhmic nodule of $5 \times 4 \mathrm{~mm}$ and a basal nodule of $6 \times 4 \mathrm{~mm}$. However, thyroid scintigraphy was normal. Breast ultrasonography showed a lipoma of $4 \mathrm{~cm}$ in diameter on the upper-outer quadrant of the left breast and a small retro-areolar lipoma of the right breast. The abdominopelvic ultrasonography was normal.

Biopsy of a neck papule showed an hyperplasic epidermis, however the dermis was normal.

The patient was treated with tretinoin lotion applied on gingival, labial and cutaneous papules for 4 months. The follow-up for 4 months showed a slight improvement of the lesions of the face. After 3 years, the cutaneous lesions of the face reappeared following the treatment withdrawal. No malignancy was observed.

\section{Discussion}

Cowden syndrome (CS), or multiple hamartoma syndrome, is a rare genodermatosis of autosomal dominant inheritance with variable penetrance and incomplete expressivity. ${ }^{4,6}$ Mutations in the PTEN gene (phosphatase and tensin homologue deleted from chromosome 10) are responsible of CS and other diseases hamartomatous tumor syndromes (PHTS). ${ }^{1}$ Cowden syndrome is a disease of the young adult (second and third decade) ${ }^{1,4}$ but it can be observed at a variable age between 4 and 75 years ${ }^{5,7}$ with an average of 39 years at the time of diagnosis. ${ }^{8}$ CS involves both sexes with a slight female predominance (sex-ratio $\mathrm{M} / \mathrm{F}=0,6){ }^{4,5}$

The CS is characterised essentially by its pathognomic mucocutaneous signs (Table 1) that are sometimes isolated or accompanied by the visceral manifestations.

The cutaneous signs, observed in 100 per cent of cases, are usually the first presenting lesions of the disease. ${ }^{6,9}$ The typical cutaneous lesions consist of small, multiple and coloured facial papules of 1 to $4 \mathrm{~mm}$ in diameter with smooth or keratotic surfaces. Theses lesions are mainly found on eyelids, forehead, nose, clustered around the mouth and sometimes on ear pavilions. ${ }^{4,9}$ The second most common 
lesions are papillomas that have the same topography but are larger in size. ${ }^{10}$ Acral keratoses are also characteristic and consist of beaded keratotic papules with often rough surface of 1 to $4 \mathrm{~mm}$ in diameter existing on dorsal site of forearms, hands and feet. ${ }^{5,11,12}$ Translucent keratotic papules are another prominent finding. They consist of small indurated papules sometimes centred by a depression found over palms and soles. ${ }^{4,5}$ Non typical cutaneous lesions can be observed such as benign tumours: angiomas (Case 1), dermal fibromas, lipomas, neurinomas, neurofibromas, nævocytic nævi, xanthomas and xanthelasmas, ${ }^{6,10}$ or malignant tumours: melanomas, basal cell carcinoma, squamous cell carcinomas and carcinomas of Merkel ${ }^{13,14}$ and as dyschromic lesions: "café au lait spots" and vitiligo.9,15

The histological features of cutaneous lesions are characteristic showing multiple trichilemmomas, associating epithelial hyperplasia, papillomatosis, parakeratosis and acanthosis ${ }^{4,10}$ but histological features of trichilemmomas were not found in all cutaneous lesions. ${ }^{16}$ The majority of trichilemmomas contain HPV DNA. ${ }^{16}$

The characteristic mucous manifestations consist essentially of papules which are pink or white smooth lesions of 1 to $3 \mathrm{~mm}$ in diameter found essentially over the palate, gums, more rarely on the labial mucosa, the ano-genital region and the nasal mucosa. ${ }^{4}$ By coalescence, papules constitute the papillomatous lesions. These papillomas are diffuse and attain the totality of the upper aero-digestive mucosa. ${ }^{4,10,12}$
Scrotal tongue $\mathrm{e}^{5,10,11}$ and gingival hypertrophy ${ }^{11,12}$ are also frequent mucous lesions of CS. Other lesions can be seen as macrocheilitis, ${ }^{10}$ polyps of hypopharynx, larynx and vocal fold $^{17}$, uvula hypoplasia, ${ }^{7,12}$ dental caries, periodontitis, gingivitis and squamous cell carcinomas of tongue and lips. ${ }^{11,15}$

CS (multiple hamartoma syndrome) often presents various visceral manifestations seen after or before reminiscent mucocutaneous pictures. Thyroid, breast, genitourinary, gastrointestinal and skeletal abnormalities are the most frequent. ${ }^{9,15}$ These clinical manifestations are summarized in Table 2.

The big variability of the expression of CS make the diagnosis difficult. In all our patients, the diagnosis of CS was based on International Cowden Consortium operational criteria for the diagnosis of CS, Version 2000. .,11 $^{2,1}$

No etiological treatment is available for this genodermatosis with high potential for visceral malignancy. However, some therapeutics can be proposed. Oral retinoids, mainly acitretine at the dose of $0,75 \mathrm{mg} / \mathrm{kg} /$ day, had been proposed for the treatment of mucocutaneous lesions. ${ }^{12}$ Their role in the prevention of cancers may be hypothesized. However, it has been indicated that digestive polyps do not respond to retinoid therapy. ${ }^{12}$ Two of our patients were treated with oral retinoids with transient improvement and relapse after withdrawal of therapy. Other treatments, such as bleomycin chemotherapy, radiotherapy with Iridium 192, surgery and CO2-laser for the multiple mucous lesions, ${ }^{4}$ local tretinoin

Table 1. Summary of various manifestations of Cowden syndrome discovered in our patients.

\begin{tabular}{|c|c|c|}
\hline & Lesions & Cases number \\
\hline Cutaneous lesions & $\begin{array}{l}\text { Cutaneous papules } \\
\text { Acral keratose } \\
\text { Translucent keratotic papules } \\
\text { Angiomas } \\
\text { Nævocytic nævi }\end{array}$ & $\begin{array}{l}4 \\
1 \\
2 \\
1 \\
1\end{array}$ \\
\hline Mucous lesions & $\begin{array}{l}\text { Oral papules } \\
\text { Oral papillomas } \\
\text { Scrotal tongue } \\
\text { Gingival hypertrophy } \\
\text { Macrocheilitis }\end{array}$ & $\begin{array}{l}4 \\
4 \\
2 \\
4 \\
1\end{array}$ \\
\hline Visceral manifestations & $\begin{array}{l}\text { Thyroid lesions } \\
\text { Fibrocystic disease } \\
\text { Breast lipoma } \\
\text { Uterine fibroma } \\
\text { Stomach polyps } \\
\text { Colon polyps } \\
\text { Glycogenic acanthosis }\end{array}$ & $\begin{array}{l}2 \\
1 \\
1 \\
1 \\
2 \\
3 \\
1\end{array}$ \\
\hline $\begin{array}{l}\text { Others } \\
\text { (associations) }\end{array}$ & $\begin{array}{l}\text { Macrocephaly } \\
\text { Dysmorphic facies } \\
\text { Deafness } \\
\text { Hydatic cyst of liver } \\
\text { Urinary lithiases } \\
\text { Lichen nitidus }\end{array}$ & $\begin{array}{l}2 \\
1 \\
1 \\
1 \\
1 \\
1\end{array}$ \\
\hline
\end{tabular}


for face lesions and salicylic acid for acral kerotoses ${ }^{9}$ were proposed. Thyroid manifestations must prompt to a regular endocrinology check-ups. ${ }^{15}$ Breast lesions require a monthly self examination, yearly ultrasonography and mammography, repeated biopsies of the suspected lesions and the avoidance of oestrogen therapy. ${ }^{10}$ The prophylactic bilateral mastectomy has been proposed by some authors because the high risk of breast cancer, ${ }^{15}$ however, this idea was not shared by other authors. Early and repeated gynaecological examinations are recommended for early diagnosis of endometrial or cervical cancers. ${ }^{15}$ Because of the low malignant potential of the gastrointestinal polyps, an endoscopic control every two years seems sufficient. Prompt intervention is indicated in any case of suspicion of malignant transformation. ${ }^{15}$ Lhermitte-Duclos syndrome should be suspected and MRI of the brain is indicated in patients who develop persistent headache. ${ }^{15}$ Sirolimus is currently undergoing a phase II study, coordinated by the National Institute of Healh (NIH) in United States to evaluate its possible efficacy in Cowden syndrome.

The prognosis of the CS is poor because of the frequent risk to develop neoplasia. No predictive factors exist to estimate the risk in the individual patient. Thyroid and breast cancers are the most frequent determinants of poor prognosis. ${ }^{5,6,13}$ Germline KILLIN methylation witch is common among patients with Cowden syndrome seems to be associated with increased risks of breast and renal cancer over PTEN mutation-positive individuals. ${ }^{16}$

The diagnosis and the management of CS is multidisciplinary. Tracking of members of the patient's family for possible other cases of CS is essential. They should undergo a meticulous clinical examination followed possibly by a genetic test in order to early diagnose and cure avoidable consequences of malignancies.

Table 2. Visceral manifestations of Cowden syndrome.

\begin{tabular}{|c|c|c|}
\hline & Benign manifestations & Malignant manifestations \\
\hline Thyroid & $\begin{array}{l}\text { Multinodular goitre } \\
\text { Hyper or hypofunction } \\
\text { Adenomas } \\
\text { Thyroiditis } \\
\text { Thyroglossal duct cyst }\end{array}$ & Cancers \\
\hline Breast & $\begin{array}{l}\text { Fibrocystic disease } \\
\text { Nipple and areola anatomic abnormalities }\end{array}$ & Cancers \\
\hline Genital tract & $\begin{array}{l}\text { Functional menstrual cycle troubles } \\
\text { Uterine fibroma } \\
\text { Ovarian benign cysts }\end{array}$ & $\begin{array}{l}\text { Uterine adenocarcinoma } \\
\text { Carcinoma of the cervix } \\
\text { Ovarian teratomas }\end{array}$ \\
\hline Digestive tract & $\begin{array}{l}\text { Polyps } \\
\text { Glycogenic acanthosis } \\
\text { Colon diverticulas } \\
\text { Hepatic cysts }\end{array}$ & $\begin{array}{l}\text { Colon adenocarcinomas } \\
\text { Hepatocellular carcinoma }\end{array}$ \\
\hline Skeleton & $\begin{array}{l}\text { Macrocephaly } \\
\text { Adenoid facies } \\
\text { Mandible hypoplasia } \\
\text { High arched palate } \\
\text { Scoliosis and pectus excavatum } \\
\text { Bone cysts }\end{array}$ & \\
\hline Neurosensory features & $\begin{array}{l}\text { Lhermitte-Duclos syndrome (LDD) } \\
\text { Meningioma } \\
\text { Deafness epilepsy } \\
\text { Eye blood vessels abnormalities } \\
\text { Glaucoma and cataract } \\
\text { Mental delay }\end{array}$ & Retinoblastoma \\
\hline Miscellaneous & $\begin{array}{l}\text { Dowen syndrome } \\
\text { Cellular or humoral immune deficiency } \\
\text { Lung cysts } \\
\text { Urinary lithiases } \\
\text { Mitral valve prolapse } \\
\text { High blood pressure } \\
\text { Sugary diabetes }\end{array}$ & $\begin{array}{l}\text { Acute leukaemia } \\
\text { Non-Hodgkins' lymphoma Osteosarcoma } \\
\text { Lung adenocarcinoma } \\
\text { Parathyroid carcinoma Liposarcoma } \\
\text { Renal cell carcinoma } \\
\text { Bladder transitional cell carcinoma } \\
\text { Prostate cancer }\end{array}$ \\
\hline
\end{tabular}




\section{References}

1. Longy M. Cowden disease and the PTEN gene: a successfully clinical and biological combined approach. Bull Cancer. 2001; 88: 1153-1158. PMID: 11792608

2. Lloyd KM 2nd, Dennis M. Cowden's disease. A possible new symptom complex with multiple system involvement. Ann Intern Med. 1963; 58: 136-142. PMID: 13931122

3. Tan MH, Mester J, Peterson C, Yang Y, Chen JL, Rybicki LA, Milas K, Pederson H, Remzi B, Orloff MS, Eng C. A clinical scoring system for selection of patients for PTEN mutation testing is proposed on the basis of a prospective study of 3042 probands. Am J Hum Genet. 2011; 88: 42-56. PMID: 21194675

4. Botma M, Russell DI, Kell RA. Cowden's disease: a rare cause of oral papillomatosis. J Laryngol Otol. 2002; 116: 221 223. PMID: 11893269

5. Longy M, Lacombe D. Cowden disease. Report of a family and review. Ann Genet. 1996; 39: 35-42. PMID: 9297442

6. Kacem M, Zili J, Zakhama A, Hadj Youssef F, Mahjoub S, Boubakri C, El May M. Multinodular goiter and parotid carcinoma : a new case of Cowden's disease. Ann Endocrinol (Paris). 2000; 61: 159-163. PMID: 10891668

7. Stanich PP, Francis DL, Sweetser S. The spectrum of findings in Cowden syndrome. Clin Gastroenterol Hepatol. 2011; 9: e2-3. PMID: 20655392
8. Eng C. Will the real Cowden syndrome please stand up: revised diagnostic criteria. J Med Genet. 2000; 37: 828-830. PMID: 11073535

9. Hildenbrand $\mathrm{C}$, Burgdorf $\mathrm{WH}$, Lautenschlager S. Cowden syndrome-diagnostic skin signs. Dermatology. 2001; 202: 362-366. PMID: 11455162

10. Boutet G, Boisserie-Lacroix M. Cowden's disease in a young girl: mammographic problems. J Gynecol Obstet Biol Reprod (Paris). 1995; 24: 686-690. PMID: 8568174

11. Ravi Prakash SM, Suma GN, Goel S. Cowden syndrome. Indian J Dent Res. 2010; 21: 439-442. PMID: 20930359

12. Cnudde F, Boulard F, Muller P, Chevallier J, Teron-Abou B. Cowden disease: treatment with acitretine. Ann Dermatol Venereol. 1996; 123: 739-741. PMID: 9636753

13. Schrager CA, Schneider D, Gruener AC, Tsou HC, Peacocke $M$. Clinical and pathological features of breast disease in Cowden's syndrome: an underrecognized syndrome with an increased risk of breast cancer. Hum Pathol. 1998; 29: 47-53. PMID: 9445133

14. Haibach H, Burns TW, Carlson HE, Burman KD, Deftos LJ. Multiple hamartoma syndrome (Cowden's disease) associated with renal cell carcinoma and primary neuroendocrine carcinoma of the skin (Merkel cell carcinoma). Am J Clin Pathol. 1992; 97: 705-712. PMID: 1575215

15. Fistarol SK, Anliker MD, Itin PH. Cowden disease or multiple hamartoma syndrome - cutaneous clue to internal malignancy. Eur J Dermatol. 2002; 12: 411-421. PMID: 12370126

16. Bennett KL, Mester J, Eng C. Germline epigenetic regulation of KILLIN in Cowden and Cowden-like syndrome. JAMA. 2010; 304: 2724-2731. PMID: 21177507 